\title{
Food Supply, Starvation, and Food As a Weapon in the Camps and Ghettos of Romanian-Occupied Bessarabia and Transnistria, 1941-44
}

\author{
Paul A. Shapiro \\ United States Holocaust Memorial Museum
}

\begin{abstract}
The Romanian regime of wartime leader Ion Antonescu concentrated the Jews of Bessarabia and Bukovyna in transit camps and ghettos, and then deported them to the Romanian-administered territory between the Dnister and Buh rivers, in southwestern Ukraine. Of approximately 160,000 Romanian Jews deported to "Transnistria," only 50,000 survived the ordeal. The Romanians, with local Volksdeutsch and Ukrainian collaborators, also massacred and were otherwise responsible for the death of approximately 150,000 local Ukrainian Jews, including the large Jewish community of Odesa. While not comparable to the Jews in number, deported Romanian Roma and local Roma were also subjected to physical brutality, forced labour, and incarceration.

Famine and starvation did not cause all Jewish and Roma deaths in Bessarabia and Transnistria. Mass executions exacted a huge toll. So did exposure to the elements, exhaustion, and typhus. Still, while there was no famine in the region, starvation was a permanent presence. Romanian authorities controlled the food supply and denied it to their targeted victims. This article describes the steps taken by Romanian occupation authorities to isolate Jews and Roma; to limit the flow of food supplies to them; to prevent them from accessing food in local markets; and to prevent help that might have been offered by those local civilians who took pity on the starving victims. Official documentation and testimonies of both officials and survivors provide a vivid picture of the consequences. Specific cases reveal factors that made the situation in one locality better or worse than that in another, or that caused a situation to improve or deteriorate. Variations notwithstanding, however, all sources lead to the conclusion that Romania's goal was to eliminate the Jews and reduce the Roma population. This made starvation, the use of "food as a weapon," an acceptable element of state policy.
\end{abstract}

Keywords: Bessarabia, Transnistria, Romania, Holocaust, Roma, starvation.

$\mathbf{F}$

amine and starvation: does this phrase describe the situation that prevailed in Bessarabia after Romania regained control of the province in mid-1941, following a year of Soviet occupation? Does it adequately describe the realities of the situation in Transnistria, the territory stretching from the Dnister to the Buh rivers that Romania occupied during World War II? Do famine and starvation explain the deaths of between 280,000 and 380,000 Jews and nearly half of the 25,000 Roma from Romania who were 
deported eastward by the Antonescu regime, or who, as local inhabitants of Transnistria, found themselves in the hands of Romanian authorities between 1941 and 1944 ?

The answers to these questions clearly must be "no," or at least "it is not that simple." There was no famine in either Bessarabia or Transnistria. Indeed, as the Romanians were shipping immense quantities of foodstuff out of Romania to their Axis ally, Germany, they were simultaneously requisitioning agricultural products from Transnistrian farms and transporting food from Transnistria into Romania proper. ${ }^{1}$ Romanian occupation authorities maintained the collective farm system that had been installed by the Soviets, and they levied food delivery requirements, just as the Soviets had, to supply themselves and contribute to the food supply available at home.

Romanian policy toward the Jews of Bessarabia and Transnistria was intentionally demeaning, brutal, and lethal. Control of the food supply and systematic starvation, however, were hardly the only murderous techniques that the Romanians deployed to achieve their policy goals regarding Jews, which had been enunciated clearly by wartime dictator and military leader "Conducător" Ion Antonescu and his Vice President of the Council of Ministers Mihai Antonescu. The policy they laid down was carried out without hesitation by their principal accomplices in the territories addressed here-the governor of Bessarabia Constantin Voiculescu, Transnistria governor Gheorghe Alexianu, and General Constantin Z. ("Piki") Vasiliu, Director General of the Gendarmerie in the Romanian Ministry of Interior. Ion Antonescu, in establishing "cleansing the terrain" of Jews ("curăţirea terenului") as national policy, declared on 4 July 1941, as Romanian forces entered Bessarabia, "The Jews have drained, impoverished, speculated against and prevented the development of the Romanian nation for centuries. There can be no debate regarding the need to escape from this

\footnotetext{
${ }^{1}$ For an early study of the roots and magnitude of Romanian economic obligations to Germany, including food shipments, see Niri. Romania's systematic pillage and removal of Transnistrian economic resources, ranging from industrial facilities and transportation infrastructure to cultural assets and food, is explored in detail, on the basis of documentation that became accessible following the collapse of Communist regimes in eastern Europe and the Soviet Union, in Solonari. The exploitation of food requisitioned from Transnistrian collective farms is addressed in Verenca and in various reports issued by the Antonescu government during the war. Germany's disappointment that these surpluses were not fully available for German use is noted in Axworthy 137. The most authoritative monographic source on Romanian-German relations during the war is Trașcă, Relaţiile Politice.
} 
plague against Romanianism . . . ."2 Four days later, Mihai Antonescu, at a meeting of the Council of Ministers, which he chaired during the Conducător's frequent absences at the front, summarized Ion Antonescu's intentions in an even more menacing tone:

At the risk of not being understood by any traditionalists who may remain among you, I am for the forced migration of the entire Jewish element from Bessarabia and Bukovina .... I am indifferent if in history we are deemed to be barbarians .... There has been no more favourable, more unfettered, more propitious or more unconstrained moment in our history for a total ethnic resolution ... and for the purification of our nation .... If necessary, use machine guns. ${ }^{3}$

Tens of thousands of Jews in Bessarabia and in Transnistria were simply shot on the spot during the advance across Bessarabia and southwestern Ukraine of Romanian military forces and the Einsatzgruppen-like "operational [killing] units" ("eşaloane operative") that had been created by Romanian authorities. Jews were murdered on the streets of Chişinău during a week of wild killing before the creation of the ghetto there, and then in massacres of able-bodied Jews from that ghetto, which were designed to reduce the potential for resistance on the eve of approaching deportations. The killing continued during the forced marches of columns of Jews from Bessarabia to Transnistria, and from location to location in Transnistria, where the standing order was to execute any Jew-man, woman, or childwho fell behind the column. On the streets of Odesa and at Dalnic on the outskirts of the city, Jews seeking to escape the warehouses that the Romanians had set ablaze, with some 16,000 Jews inside, were met with machine-gun fire. In the Berezivka (Berezovca) district, Volksdeutsch colonists eagerly participated in executing Jews being evacuated north from Odesa. In Holta (Golta) district, over several weeks in December 1941January 1942, between 48,000 and 52,000 Jews were shot to death at Bohdanivka (Bogdanovca), Domanivka (Domanovca), and Akmechetski Stavky (Acmecetca).

At Bohdanivka, as at Dalnic, Jews were burned alive. One of the pigsties where they were being held was set on fire by the Romanians, as a means of "encouraging" other Jews interned on that collective farm to proceed more willingly to the shooting site. Jews were hanged from lampposts on the streets of Odesa in retribution for the dynamiting of the military headquarters building, which in reality had been mined by withdrawing

\footnotetext{
2 Order of 4 July 1941, Ion Antonescu to military and gendarmerie units, in Evreii din România între Anii 1940-1944: Perioada 1: 256-57. All translations are my own.

3 The minutes of the meeting can be found in Evreii din România între Anii 19401944-Problema 264-68; also excerpted in Carp 3: 92.
} 
Soviet forces, not by Odesan Jews. ${ }^{4}$ And many Jews quite simply were left exposed to the weather with neither shelter nor heat and froze to death in ghettos and camps across Transnistria, especially during the brutally cold winter of 1941-42. Roma deportees who arrived later were also deprived of adequate shelter and succumbed in significant numbers to cold, disease, and exhaustion. ${ }^{5}$

Yet even within this litany of murder techniques, the impact of the food factor manifested itself at all stages of the persecution and destruction process. Hunger and starvation became a daily reality because of the rules established by the regime, according to which Jews and Roma in most cases were supposed to provide for their own food needs through work. The disproportionately large number of elderly, women, and children relative to able-bodied workers among the victims and the severe restrictions placed on their freedom to go in search of either work or food made this a virtual impossibility. The refusal of potential employers, as well as many actual users of forced labour, to pay or feed Jewish and Romani labourers further aggravated the tragic situation confronting the persecutees. The authorities controlled food supplies, and the needs of everyone else, both locally and in Romania proper, took priority over the needs of Jews and Roma. Both Jews and Roma found themselves in a constant state of panic regarding food. Malnutrition was pervasive, and starvation was common. Moreover, in some specific instances control of diet was used in premeditated fashion as a lethal weapon, designed to kill.

There has been no comprehensive study of this issue, but a wealth of documentary and testimonial resources that address the food issue exists, enough to support a serious monographic study. In the pages that follow, it is possible to present only samples of those sources as they relate to the transit camps and ghettos in Bessarabia, to Jewish deportees and local Jews

4 For well-documented accounts in English of Romania's involvement in the Holocaust, including these events, see Ioanid, Holocaust; Ancel, History; Ancel, Transnistria; and Shapiro, Kishinev Ghetto. Because the majority of citations in this essay are to sources originally in the Romanian language, when they first appear I have provided in parenthesis the Romanian spellings of Ukrainian localities that were in Romanian-administered Transnistria during World War II.

5 The recently completed third volume of the United States Holocaust Memorial Museum Encyclopedia of Camps and Ghettos 1933-1945, dedicated to the camps and ghettos under European regimes that were aligned with Nazi Germany, includes detailed information, with extensive citations of primary source material, regarding the camps and ghettos established by Romanian authorities in Bessarabia, Bukovyna, and Transnistria, including the majority of those to which reference is made in this article. See Megargee et al. 569-830. 
in Transnistria, and to Roma deportees to Transnistria. The perspectives of Romanian authorities and of their victims emerge clearly from this material.

\section{THE BESSARABIAN TRANSIT CAMPS}

According to the 1930 Romanian census, 206,958 Jews lived in Bessarabia. The number had grown to an estimated 225,000 or more a decade later. On the eve of Operation Barbarossa, General Vasiliu informed the leadership of gendarmerie units that were to proceed into Bessarabia with the first wave of the military attack that "cleansing the terrain" meant "the extermination on the spot of all Jews in rural areas, [and] enclosing in ghettos the Jews in urban areas ...."6 Despite the massive killing that followed, not all the Jews in rural towns and villages were murdered in this first wave. A sequence of orders followed, first, to "identify and arrest all Jews, of every age and gender, still found in rural districts,"7 then, to ensure "the removal of Jews from the villages," 8 and finally, on the order of Governor Voiculescu, to create camps in which all Jews in rural areas were to be concentrated and subjected to physically exhausting forced labour on roads, bridge repair, earthworks, and similar projects. Jews in cities were to register within three days and were also to be used for forced labour. In Chişinău, Voiculescu ordered "acceleration of the operation of establishing a ghetto." 9

The concentration and isolation of Jews in restricted rural locations immediately triggered a crisis of food supply, quickly recognized by authorities on the ground and felt by Jewish internees. Transit camps were established in response to Voiculescu's order and encircled with barbed

6 United States Holocaust Memorial Museum Archive (USHMM) RG25.004/Romanian Information Service Archives, Roll 16, File 22539, vol. 32, ff. 5-6, Document of [Postwar War Crimes Trial] Indictment-Case 547/1950; the indictment, including the quoted passage, is also excerpted in facsimile in Ancel, Documents 5: 2-6 and 6: 441-55.

${ }^{7}$ Circular Order No. 1 of 8 July 1941, from [Teodor] Meculescu, Chişinău Inspectorate of Gendarmerie, excerpted in Carp 3: 92.

8 USHMM RG-25.003/Archives of the Romanian Ministry of National Defense, Roll 125 (old 655), Fond Guvernămîntul Basarabiei, Cabinet Militar, Folder 25, ff. 520-22, Copy of telegraphic order No. 143 from Vice President of the Council of Ministers to Voiculescu, 12 July 1941.

9 This order was widely distributed. See, for example, USHMM RG-54.001/State Archival Services of Moldova, Roll 17, Fond 680, Opis 1, Folder 4230-1, f.1, Voiculescu Order No. 61 of 24 July 1941 to Inspectorate of Police Chişinău, registered as received by the Inspectorate on 28 July. The same order went to all county prefectures, mayoral offices, the Military Commander of Chişinău, police offices, and gendarmerie offices. The order has been published in Benjamin 214. 
wire. They were intended by the Romanians as temporary holding sites, where Jews would be kept until it was possible to deport them, first across the Dnister into Transnistria and then to German-occupied Ukrainian territory beyond the Buh. ${ }^{10}$ The principal transit camps were large. Statistics have survived in Romanian government records. On 1 September 1941, just a few weeks after the re-entry of Romanian forces into Bessarabia, for example, there were 23,549 Jews in the transit camp at Vertiujeni; 11,762 at Edineţ; 10,737 at Mărculeşti; and 10,356 at Sokyriany (Secureni).

Figure 1. Map of camps in Old Romania, Bessarabia, and Bukovyna. Courtesy of the United States Holocaust Memorial Museum. ${ }^{11}$

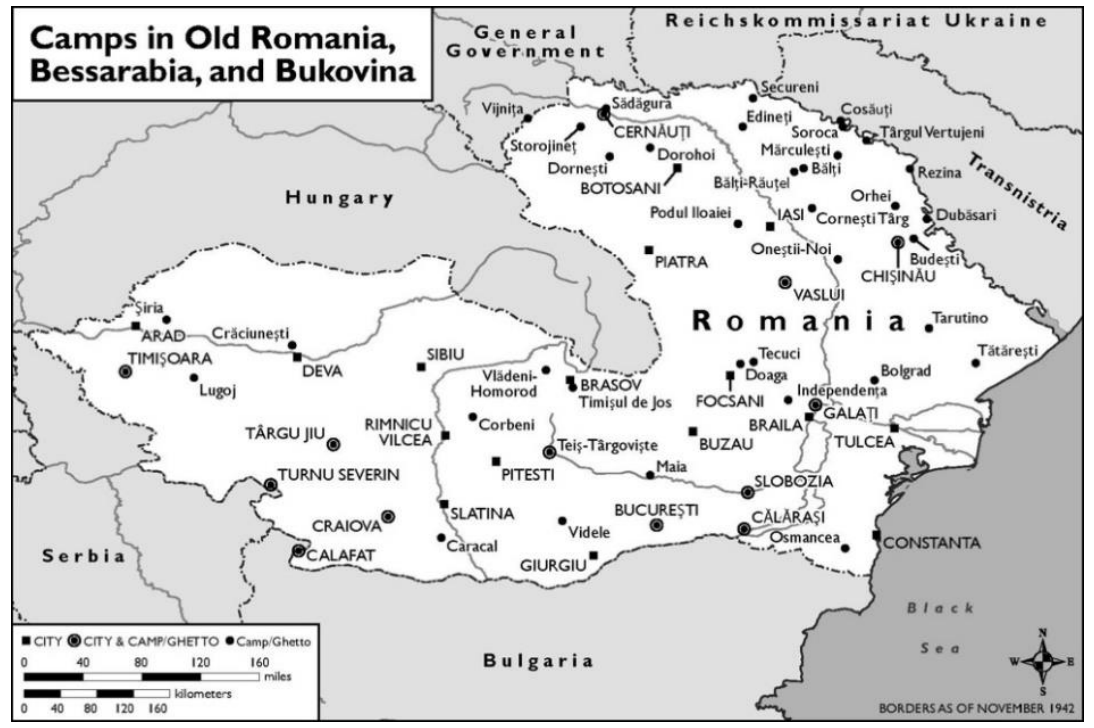

10 The Romanian government's desire to deport the Jews of Bessarabia and Bukovyna eastward immediately, first across the Dnister and then across the Buh, was frustrated from the start by German unwillingness to have masses of Jews pushed into territories under German control where military operations were continuing. By formal agreement concluded on 30 August 1941, the Romanians assumed administrative authority in Transnistria, but were constrained to postpone deportations across the Buh until the conclusion of military operations. The concentration of Jews in camps and ghettos in Bessarabia, and then in Transnistria, was one result of this contretemps between Romanian and German authorities. See Ioanid, Holocaust, 115-22.

11 This and the other two maps reproduced in this article first appeared in United States Holocaust Memorial Museum, Encyclopedia of Camps and Ghettos 1933-1945, vol. 3, Indiana UP, 2018. 
On 17 July, General Ion Topor, Grand Praetor of the Romanian Army (chief of the military gendarmerie) reported to General Staff Headquarters that several thousand Jews were already in detention at Bălţi and that additional Jews were being sent in the direction of Bălţi by various advancing army units. He reported that he lacked the manpower to guard them and lacked sufficient food for the 8,500 Jews that he anticipated would soon be concentrated there. Describing the situation as untenable, Topor suggested to his military leadership and to the Ministry of Interior that the Jews be sent to the interior of Romania. ${ }^{12}$ General Nicolae Tătăranu at General Staff Headquarters responded that the internees were to stay put and indicated that they should be fed by the local Jewish community. This proposed solution to the food problem was totally unrealistic. The Bălţi Jewish community had already lost its leadership and many of its members to shooting squads, and the surviving Jews were being forced into a ghetto. ${ }^{13}$ The Ministry of Interior communicated to every gendarmerie inspectorate Ion Antonescu's confidential orders that all Jews in detention were to be put to hard labour and that Jews who did not work were not only to be denied a food ration, but also were to be prevented from receiving food from any other source. ${ }^{14}$

The preponderance of the elderly, women, and children among the internees-able-bodied men having been drafted or evacuated by the Soviets or shot on sight by the advancing Germans and Romanians-as well as the isolation imposed on the Jews gave the lie from the very start to the notion that internee populations would be able to feed themselves through work. Nor was the compensation for labour that the government suggested sufficient for this approach to be viable. Moreover, it rapidly became clear that employers, actual or potential, were not anxious to pay or even feed

\footnotetext{
12 USHMM RG-25.004, Roll 25, Fond 20725, vol. 9, f. 305, Report No. 223 of 17 July 1941 from Grand Praetor Topor to General Headquarters; USHMM RG-54.001, Roll 22, Fond 1607, Opis 1, Folder 3-1, f. 460, Telegram No. 229 of 18 July 1941 Topor to Ministry of the Interior.

13 See Tătăranu's note in the margin of Topor's report (USHMM RG-25.004, Roll 25, Fond 20725, vol. 9, f. 305, Report No. 223 of 17 July 1941 from Grand Praetor Topor to General Headquarters).

${ }^{14}$ Ancel, Documents 5: 19, General I. Popescu, Undersecretary of State, Ministry of the Interior, very urgent/confidential Order No. 5011 to the General Inspectorate of the Gendarmerie, 18 July 1941. The content of Antonescu's order also can be found in an official communiqué of the Ministry of Interior dated 18 July 1942, reproduced in Evreii din România între Anii 1940-1944: Perioada 1: 396.
} 
Jewish labourers when they understood that they were not going to be forced to do so. ${ }^{15}$

The result was predictable. In a postwar testimony, Vertiujeni resident Lida Molceanov described the situation in the transit camp outside Vertiujeni. Surrounded by barbed wire and guarded by soldiers, the Jews were forced to pave the streets of the village. But when Molceanov's mother gave Lida small bags of potatoes, polenta, or other bits of food to throw over the wire, the guards chased her and other children away, sometimes beating them. All the while inside the wire "were little children with their hands stretched out to those passing by pleading, 'Give me a piece of bread! Give me a piece of bread! Please give me a piece of bread to eat!'” Another Vertiujeni resident, Valeriu Bogdan, noted that the Jews had no choice other than to sell their valuables or trade them for food. While some internees were able to work for more wealthy villagers (mostly providing tailoring services) in exchange for food, which they took to their families in the camp, Bogdan remembers that the road he walked to school passed by the camp and that he would share his lunch "with the Jews who were begging by the camp fence ...." Even as a child he was shocked by the number of people who died in the camp and were buried in the Jewish cemetery outside the village. About twenty to thirty bodies per day, he recalled, all buried "in a big pit."16

Romanian authorities were aware of the rapidly deteriorating situation in the transit camps. On 10 September 1941, Bureau II (Counterintelligence) of the Romanian army reported on the situation in the camps in three Bessarabian districts-Bălţi, Soroca, and Khotyn (Hotin). There were three camps in the Bălţi district-Limbenii Noi, Rășcani, Răuțel—with a total of 9,141 internees; the camp of Vertiujeni in Soroca district, with "approximately 23,000 internees"; and two camps in Khotyn districtSokyriany and Edineţ-with a total of 22,118 inmates. The mayor's office in the city of Bălţi was feeding the internees, "providing two-thirds of a loaf of bread daily per person and once a day a portion of corn meal cooked in oil." "Both the bread and serving of corn meal," the report noted, were "of very poor quality and totally insufficient." Medical care and sanitary facilities were lacking in the camp, and the death rate in was rising. In the camp at

\footnotetext{
15 On pay scales set by the government and the reluctance of "employers" to follow them, see Shapiro, Kishinev 49-51.

16 Testimony of Lida Molceanov, Moldova Documentation Project, USHMM, RG$50.572 * 0013$, Box 1, CD 1; and testimony of Valeriu Bogdan, Moldova Documentation Project, USHMM, RG-50.572*0014, Box 1, Tape 1. I want to express special appreciation to my friend and long-time colleague Radu Ioanid, who graciously shared with me information regarding the unique testimonial sources cited in notes $16,18,19,27$, and 39 .
} 
Răuţel, where the survivors of the Bălţi Jewish community had been moved from the ghetto in town, a scarlet fever epidemic had broken out, with ten to fifteen people dying each day and "the cadavers lying in the midst of the internees," for lack of a place to put them. The situation was even worse in Soroca district, where neither the mayor's office nor the district prefecture assumed any responsibility for feeding the internees. "The prefecture gave orders that the Jews obtain their own food," the report stated, and continued, "the majority of internees, however, have no money and are forced to simply endure hunger." In Khotyn, the situation was similar. The report concludes:

[T] aking into consideration the lack of food, the lack of shelter (in some camps in the current bad weather they must stay outside in the rain), and especially the lack of sanitation, these camps will soon become nests of infection and the spread of all types of contagious diseases which will endanger the population and the troops, even if we establish a cordon sanitaire, since we know that hunger will succeed in breaking through any barrier. ${ }^{17}$

Reports such as this definitely reinforced the Romanians' determination to remove the Jews and hastened their preparations to deport all surviving Bessarabian Jews eastward into Transnistria.

\section{BESSARABIAN GHETTOS}

In terms of food policy and access to food, the situation in the short-lived ghettos in Bessarabian cities and towns deteriorated less rapidly than in the transit camps, but in the final analysis was little different. The policy of assuming that Jews would feed themselves through work was flawed for reasons similar to those that applied in the transit camps-there were too few able-bodied Jews relative to the entire ghetto population, and "employers" were unwilling to pay or feed Jewish workers enough to enable them to provide for the ghetto's needs. To these factors was added the sad reality, regularly reported by government officials, that the Christian population in Bessarabian towns was antagonistic and complained when Jews were taken out of the ghetto to work sites. They were fearful that the Jews might attempt to return to their homes, which were already occupied by others, or try to remove items from their former homes to trade for food, when those items had already been appropriated by new inhabitants or

17 Arhivele Militare Române (Romanian Military Archive-AMR), fond 1693Comandamentul Etapelor de Est, dosar nr. 16, f.23+verso, "Report of 10 September 1941 on the Situation of the Jews in this Command," published in Trașcă, "Chestiunea evreiască," document 101, 262-63. 
former neighbours. This attitude of the local population, the growing fear of epidemics, and orders received by late summer in preparation for deportations to restrict entirely the movement of Jews beyond the confines of the ghettos also limited the number of Jews actually used for labour or able to obtain food (Shapiro, Kishinev 23-24).

Many powerful descriptions of the situation in smaller ghettos exist, provided by Jewish survivors, Christian eyewitnesses, and official Romanian government and military reporting. For example, a Christian resident of the city of Orhei, Gheorghe Stratan, born in 1920, recalled in his testimony the establishment of the ghetto, when entire families were arrested throughout the town and taken to the ghetto, allowed to take with them "nothing other than food, mostly bread." He remembered acquaintances of Jews sometimes bringing food to those arrested and sneaking it through cracks between the wooden planks that surrounded the ghetto. In the same breath, however, he also described the brutality of the police guarding the ghetto, who did all that they could to prevent the locals from feeding or otherwise helping the Jews. Noting that the Jews were not permitted to exit the improvised camp, he spoke vividly of those who died, emphasizing the authorities' lack of respect for the Jews, even after death, reflected in the way the bodies were simply thrown into a truck and hauled away. ${ }^{18}$

Survivor Lida Burihovici was interned together with ninety-six other Jews in the ghetto of Izmail (Ismail) at the southwestern edge of Bessarabia. She described in frightening detail the abuses to which internees were subjected: shoved, beaten, kicked; sick and elderly taken away and never seen again; young girls raped in front of their families. As for food, she declared:

[W] had only what we had brought with us. When we left our home my uncle and I wanted to bring clothes, but mama said to bring food. She put together two small bags with dishes and a sack full of food, but they were very heavy and we abandoned them on the way. So our food was finished quickly. We were lucky that local Ukrainians would throw us something over the fence to shove into our mouths .... ${ }^{19}$

The situation in the large ghetto in Chişinău, the provincial capital, was also perilous. At its high point there were 11,525 Jews crammed into a few streets in the very centre of the city, but separated from the world outside by a closely guarded wooden fence. In the first weeks of the ghetto's

18 Testimony of Gheorghe Stratan, Moldova Documentation Project, USHMM RG$50.572 * 0026$, Box 1, Tape 1 .

19 Testimony (part 2) of Lida Burihovici-Havas, interviewed by Andrea Ghita on 3 October 2010, accessible at http://www.acum.tv/articol/18373 under title "Mărturii cutremurătoare despre calvarul din Transnistria." Accessed 15 Aug. 2017. 
existence, Romanian authorities made an effort, albeit insufficient, to make food available in the ghetto. The authorities appointed a Jewish Ghetto Committee, and on 1 August, Chişinău garrison commander Colonel Dumitru Tudose agreed to the operation of a bakery, which was to be provided with flour from the Chişinău garrison. The ghetto committee was to use the money from bread sales to Jews who could afford to pay to assist the destitute. Tudose also authorized the establishment of a ghetto marketplace, and peasants were permitted to enter the ghetto to sell produce and other food products. Conditions, however, deteriorated rapidly. After a few weeks even official reports by the Regional Police Inspectorate stated that the availability of food in the ghetto was very limited and the prices very high. The supply of flour to the bakery was inadequate, providing for the distribution of only one hundred grams of bread per internee per day. The Jewish Committee, trying to cope with the deteriorating situation, operated a soup kitchen where two hundred families were fed soup and corn meal mush ("mămăligă") once daily. But Romanian authorities reported ten to fifteen deaths daily due to the lack of food, limited medical care, and inadequate sanitary conditions in the ghetto. ${ }^{20}$

A list of Jews who succumbed to the rapidly worsening conditions in the ghetto was prepared daily. Nearly all of the lists have survived. Small children and the elderly were most susceptible, and the death lists reflect their vulnerability: two adults aged sixty-five and ninety, and seven-and-ahalf-month-old Victoria Katz died on 18 August; four adults aged sixty-seven to eighty, on 19 August; four women aged fifty-nine to eighty and a four-dayold baby on 31 August. By early October, the death rate among the Jewish internees was averaging thirteen to fifteen per day: twelve people on 1 October, nine over age sixty, and a five-year-old child; nine the next day, including an eighty-nine-year-old man and a one-year-old child; fifteen on 45 October, including eleven adults aged sixty-six to eighty-two and a threeweek-old baby. The pace slowed only when deportations reduced the ghetto population. The running total of recorded deaths from "natural causes" reached 441 by the time deportations began. A commission of inquiry appointed by Ion Antonescu to report on irregularities in administration of

\footnotetext{
20 USHMM RG-54.001, Roll 17, Fond 680, Opis 1, Folder 4230-1, f. 13, Memorandum No. 804a of 3 August 1941 from Chişinău Police Station to the Regional Inspectorate of Police. USHMM RG-54.001, Roll 1, Fond 706, Opis 1, Folder 22, f. 21, "Nota informativă," undated; USHMM RG-25.004, Roll 25, Fond 20725, vol. 7, ff. 297-317, Chişinău Regional Police Inspectorate Counterintelligence Bulletin for 10-20 September 1941.
} 
the ghetto considered this number "not very high," although it represented, on an annual basis, a "natural" death rate of fifteen to twenty percent. ${ }^{21}$

At the end of August Governor Voiculescu reported to Antonescu that only a few Jews in the ghetto had the money or other possessions necessary to sustain themselves, and that only approximately four hundred men and four hundred women remained physically able to work. The rest had no means to support themselves. ${ }^{22}$ Even those who might have worked faced serious obstacles. Bessarabia Police Inspector Alfred Pacsimade reported to Voiculescu that Jews had been "used as forced labourers for public purposes, mainly by the army, official installations, and by city authorities." He continued,

They were supposed to be paid twenty-five lei per day, which they did not receive, because the authorities for which they worked had no funds. Today the authorities, knowing that Jewish labour is supposed to be paid for, no longer request them, thus depriving the Jews of the single possibility they had to secure their own survival ....23

The chief of the police unit assigned to work inside the ghetto reported that deprived of any income, the Jews were "selling their last possessions to survive." He signalled the danger the ghetto represented to the surrounding Chişinău community and to the peasants who entered the ghetto to sell food or barter with the Jews: "Everything is crawling with parasites . . . a hotbed

21 USHMM RG-25.003, Roll 131 (old 657), Folder 35, ff. 368-72, Report No. 1537 of 23 August 1941, Chișinău Military Commander, Col. D. Tudose, to the Administration of Bessarabia (Voiculescu); USHMM RG-25.004, Roll 25, Fond 20725, vol. 7, "Ministry of Interior, Arhiva Operativă," ff. 288-91, Report No. 2147 of 2 September 1941 from Chişinău Military Commander Eugen Dumitrescu to Leadership and Administration of Bessarabia (Voiculescu). A number of death lists for October are at USHMM RG25.004, Roll 25, Fond 20725, vol. 7, ff. 277-90. Additional reports regarding mortality numbers and the names of the deceased, covering the period from 16 August to 5 October, are in USHMM RG-25.003, Roll 131 (old 657), Folder 35; see ff. 372, 398, 404, 407, 413, 424-25, 431, 435, 438, 443, 447, 454, 458, 462, 466, 470, 474, 493, $494,496,499,504,505,518,527,529,544,549,554$. For the commission's report and conclusions, see USHMM RG-54.001, Roll 1, Fond 706, Opis 1, Folder 69 (Folder title: Ancheta neregulilor în administrarea Ghettoului Chişinău, 1941) (henceforth Inquiry Report).

22 USHMM RG-25.004, Roll 25, Fond 20725, vol. 7, ff. 260-61, Voiculescu Communiqué No. 772/C to the Presidency of the Council of Ministers, 31 August 1941; and same folder, ff. 263-75, Chișinău Regional Police Inspectorate Counterintelligence Bulletin for 20-31 August 1941.

23 USHMM RG-54.001, Roll 17, Fond 680, Opis 1, Folder 4230-1, ff. 89-90. Report No. 281-C of 27 August 1941 from Pacsimade, Bessarabia Inspector of Police to Voiculescu. 
of infection ... [and] the selling of clothing, linens, carpets, pillows, comforters to the peasants ... makes the ghetto a centre for the transfer of every kind of microbe by the principal carrier of disease, fleas." ${ }^{24}$ Inside the ghetto, the internees' concern over the lack of food was reaching desperation. The police chief reported, "they have neither food nor clothes nor money. They are wondering what they will do in the winter."25

As the noose around the ghetto tightened with the approach of planned deportations and in response to the growing fear of disease, peasants who had once supplied the ghetto market were denied entry. Even military and police officers were searched on entering and exiting the ghetto to prevent the exchange of possessions, favours, and food. In mid-September, Voiculescu refused the Chişinău garrison commander's request to continue to allow Jews designated by the ghetto committee to leave the ghetto, under escort, to procure food supplies. ${ }^{26}$ As deportations began and word spread that the internees would have to provide for their own food for the journey, the Jews' desperation to obtain food to take with them peaked. A local Christian Orthodox high school student who witnessed the scene later described the exploitation of the situation by the local population:

I watched helplessly the pillaging of a column of Jews on the way to Transnistria in mid-winter ... . Not all Bessarabians are heartless, but unfortunately there were plenty who for a loaf of bread demanded and got an astrakhan fur collar or fur hat. The price of a roast chicken was at least a fur-lined jacket .... I will never forget these images. ${ }^{27}$

\footnotetext{
24 USHMM RG-54.001, Roll 7, Fond 679, Opis 1, Folder 6586, f. 414, Report No. 529 of 6 October 1941 from Chief of the Ghetto Police Station to Chief of Chişinău Municipal Police.

25 USHMM RG-54.001, Roll 6, Fond 679, Opis 1, Folder 6586, f. 333, Report No. 5915S[ecret] of 29 September 1941 from Chișinău Police Station to Chişinău Regional Police Inspectorate.

26 USHMM RG-54.001, Roll 1, Fond 706, Opis 1, Folder 22, f. 26, Intelligence Note of 19 September 1941; and f. 271, Secret Communiqué No. 244-C of 24 September 1941, from Voiculescu to Dumitrescu.

27 Blog testimony entitled "Gropile erau deja săpate și au fost împinși în ele și acoperiți cu pământ," 1 November 2009, at https://maghiaromania.wordpress.com/2009/11/01/gropile-erau-deja-sapate.

Accessed 15 Aug. 2017. The full blog statement posted on 25 October 2009 by [Dumitru] Stoian can be found as part of the blog of Petru Clej at http://acum.tv/articol/10523. Accessed 15 Aug. 2017.
} 


\section{DEPORTATIONS FROM BESSARABIA TO TRANSNISTRIA}

Having decided that the Jews would be deported east on foot, and given the rapid deterioration of the condition of internees in the transit camps and ghettos, Bucharest ordered the deportations to begin. On 7 September, Grand Praetor Topor issued a written instruction to Bessarabia Gendarmerie Inspector Meculescu to begin the deportation of Jews on 12 September, starting with the transit camp at Vertiujeni. The abbreviated guidelines in Topor's "Note" of 7 September became the standard for deportations from other locations in Bessarabia as well, including the ghettos. The guidelines are worthy of attention:

1. The evacuation of Jews begins on 12 September with the camp at Vertiujeni....

2. Groups of 1,600 at most, including children; but they will cross the Dnister at a rate of no more than 800 per day.

3. Forty or fifty carts for each group.

4. Groups will leave Vertiujeni every other day.

5. A gendarmerie officer will cross [the Dnister] with every group.

6. Crossing without [completion of] any formalities.

7. [Evacuation] Routes will be established by Lt. Colonel Palade .... .

8. Two platoons [of gendarmes] will provide supplemental assistance.

9. Gendarmes at territorial posts [along the way] to aid in cleansing the terrain and burying the dead, using local inhabitants [for this purpose].

10. Way to deal with those who do not comply? "Alexianu."

11. No customs procedures. Anyone who steals [Jewish goods] will be shot. $^{28}$

On 10 October, as deportations from the transit camps were being completed, Meculescu issued similar, but more elaborately spelled out, instructions for the deportation of Jews from the Chișinău ghetto and from the other ghettos in Southern Bessarabia as well-Bolhrad (Bolgrad), Cahul, Kiliia (Chilia), Izmail, and Vâlcov. Instructions regarding the Tarutyne (Tarutino) ghetto were issued separately a few days later. The routes of forced march and the Dnister crossing points were designated for each camp or ghetto, with hand-drawn maps attached to the instructions illustrating

28 USHMM RG-25.004, Roll 25, Fond 20725, vol. 9, ff. 287-89, Communiqué No. 1550 of 11 September 1941 from Meculescu to Government of Bessarabia (Voiculescu), covering Topor "Note" of 7 September 1941; and f. 278, Minutes of Deposition of Teodor Meculescu, 28 April 1945. A copy of the Topor "Note" is also at RG-54.001, Roll 1, Fond 706, Opis 1, Folder 22, f. 43. The instructions were summarized in Inquiry Report, Part 1. 
the routes to be taken by each column and the pace at which the columns were to move. ${ }^{29}$

Recognizing that many internees would be unable to endure the deportation on foot and that few internees would be able to carry even the "strictly necessary" personal items they would be allowed to take with them, the instructions called for the gendarmerie and other "administrative authorities" to provide 100 to 120 carts for each convoy leaving Chişinău. Other provisions in the instructions, however, made it clear that cleansing the terrain of Jews in Bessarabia took precedence over any concern regarding the deportees' physical survival. Because neither Voiculescu nor Topor were willing to allocate supplies for the deportees, Meculescu stipulated that the Jews in the convoys would have to feed themselves - a virtual impossibility for many internees, certain to be made even more difficult by the speed and conditions of the deportations. The deportation instructions required that maximum effort be made to avoid having the columns of deportees pass through towns and villages or come into contact with the local population, making the procurement of food virtually impossible. ${ }^{30}$

The increasingly dismissive attitude of Romanian authorities toward the survival of the Jews could be seen in differences that appeared between procedures established for the first deportations and those that came later. While the deportation orders for the Vertiujeni camp, for instance, called for arrangements to be made for the Jews to sleep in sheds and stables along the way, no shelter was foreseen for the Jews from Chişinău, who despite exhaustion and low physical resistance, were forced to overnight in late October weather in open fields along the route of march. Recognizing the likely consequences of the orders - that the planned forced marches would become "death marches"-the drafters of the instructions chose to use veiled language when they directed the officials who would manage the

29 USHMM RG-54.001, Roll 1, Fond 706, Opis 1, Folder 22, ff. 51-66, Secret Communiqué No. 2830 of 10 October 1941 from Meculescu to Gendarmerie Legions at Cahul, Chilia, Ismail, Orhei, and the 23rd Police Company, covering "Instructions relating to the evacuation of the Jews of the Chişinău ghetto and of Southern Bessarabia," with attached maps and schedules of forced marches. A copy of the instructions, with a slightly revised version of the covering Secret Communiqué No. 2830, to include transmittal also to the Eighty-Second Police Company, is at USHMM RG-25.003, Roll 126 (old 656), Folder 29, ff. 608-16 [handwritten]. The special instructions regarding Tarutino, sent by Meculescu to the Gendarmerie legions at Cetatea Albă and Chilia Nouă on 23 October 1941, continue on ff. 617-20 [handwritten].

30 Minutes of Deposition of Teodor Meculescu, 28 April 1945, USHMM RG-25.004, Roll 25, Fond 20725, vol. 9, f. 278. 
deportations to "take appropriate measures during the marches to ensure the cleansing of the terrain, collecting those who fall behind and burying immediately any that may eventually cease living." A final admonition from Governor Voiculescu warned that the units in charge would be "held responsible if a single Jew remains in either an urban or a rural area after the completion of this operation." 31

A description of the horrendous conditions that prevailed during these deportations was provided by a Romanian officer who participated in the deportations from Edineţ and Sokyriany transit camps. He also revealed the meaning of the code word "Alexianu," which was not only a direct reference to the person who had been appointed governor of Transnistria, but also, indirectly, a reference to the broadly understood anticipated fate of the Jews being sent there. Questioned in December 1941 by the commission of inquiry looking into irregularities in administration of the Chişinău ghetto, Lieutenant Augustin Roşca declared:

The term we used for the Jews was "crates." We had enough carts because people knew we would pay 250 lei a day, but the drivers took more money [from the Jews], one hundred lei per person, and when they came to the foot of a hill, they would demand another hundred [threatening to put the Jews out, at the risk of their lives]. Cart drivers even came out of the villages without being summoned because for them this was a good way to make some money .... General Headquarters [instructed] ... that those who could not keep up with the convoy, either because they were weak or because they were sick, should be executed .... I was ordered to send out, two or three days before the departure of the convoys, a [sergeant] ... to arrange for pits to be dug big enough to hold about one hundred people, at appropriate locations, that is, far from villages, so that the cries and shots [would] not be heard .... The pits had to be at ten-kilometre intervals, where those who could not keep up with the column would be assembled. For those who could not even make it to the pits, it would be "Alexianu," which was code for execution on the spot.... Pre-military youths [recruited locally] dug the pits, put the bodies in, and covered them.... Peasants stood along the way, like crows waiting to scavenge something .... At the first ditch, which was just five kilometres along the way, I left fifty to sixty people behind, guarded by about six gendarmes, who stayed there until evening and then executed them. The columns moved with great difficulty and

31 USHMM RG-54.001, Roll 17, Fond 680, Opis 1, Folder 4230-2, f. 308, Secret Communiqué No. 368/C of 10 October 1941 from Voiculescu to all Prefectures, the Bessarabian Gendarmerie Inspectorate, Chişinău Police Inspectorate, and the Chişinău Military Command. 
disorder because of the children, women, and elderly. About 120 Jews from the first convoy were buried in other ditches along the way. ${ }^{32}$

The elderly, the sick, women, and children vied for space in the carts, and those who still had possessions loaded them in as well. Both the escort guards and onlookers along the deportation route were tempted by the "wealth of the Jews" passing within their reach. Robbery of the convoys was a constant problem. Peasants lined up along the road waiting for the column to stop for the night so that they could steal or, more ominously, waited for stragglers who had fallen behind the column to be executed so that they could strip the bodies of possessions, clothes, and shoes. The possibility that those same individuals would feed the Jews was far-fetched indeed. The confusion, the assembled goods, the vulnerability of the deportees, and the pressure created by rigid deadlines all combined to increase the suffering and the number of Jews killed during the deportations. On these forced marches, exposure, illness, exhaustion from the effort to keep up with the convoy, and weakness from a starvation diet before the deportations began took a deadly toll. For the troops and gendarmes escorting the columns, the pressure to meet a deadline set by Ion Antonescu to have all Jews out of Bessarabia by 31 October made shooting Jews preferable to trying to ensure that as many as possible reached the Dnister.

The bodies of thousands of Bessarabian Jews still lie today in those ditches every ten kilometres along the routes the convoys were forced to tread. The Jews who reached the Dnister crossing points arrived in terrible condition. A Jewish woman deported by train from Bukovyna testified of her encounter with a column of Bessarabian Jews at Otachi (Atachi):

They came on foot, we by train-it made a big difference. They were walking skeletons, dressed in rags, just shreds, and when they saw us ... they tried to leave the column and come toward us to ask for help. The gendarmes would not permit it and told us that these people were covered in fleas and carrying typhus, which was true. Thus, they extended their hands toward us, and we shied away .... Some among us, violating every rule and overcoming fear, approached the column and gave them something to eat .... Meeting this group was horrible because we realized that we could become just like them. ${ }^{33}$

\footnotetext{
32 USHMM RG-25.004, Roll 25, Fond 20725, Folder "Ancheta Georgescu Mihnea şi alţii," vol. 9, f. 286, Declaration of Lt. Augustin Roşca, 23 December 1941.

${ }^{33}$ Interview with Sarina Ionescu in Holocaustul evreilor români 179.
} 


\section{FORCED MARCHES IN TRANSNISTRIA}

The majority of the Bessarabian Jews who were deported to Transnistria did not survive. Most failed to survive even the first winter. Arriving in weakened physical condition, they were forced to march from place to place through difficult terrain, always with the dreaded "Alexianu" order hanging over the head of any man, woman, child, grandfather, or grandmother who fell behind. Those who survived the forced marches were put to forced labour or concentrated in ghettos and on collective farms in the Holta region along the Buh River, where the conditions for sustaining life were minimal and where food, water, medicine, and outside contact were denied them. The winter of 1941-42 was particularly harsh. Deportees succumbed in massive numbers to freezing temperatures, starvation, and typhus, and tens of thousands of local Jews and deportees from Bessarabia were executed in the districts of eastern Transnistria along the Buh.

Still, Transnistria and Bessarabia were not the same. A recent study, which compared the behaviour of non-Jewish civilians in Bessarabia and in Transnistria, has demonstrated convincingly that the local Ukrainian population of Transnistria adopted a much more humane attitude toward both Jewish deportees from Bessarabia and local Transnistrian Jews than non-Jews had shown toward persecuted Jews in Bessarabia (see Dumitru). One area where the contrast of behaviour was most striking was in the readiness of locals to attempt to provide food and water to the exhausted, parched, and starving Jews in the forced march columns. Recognizing the risk, some people threw food to the Jews from a distance. Peasant women sometimes put food bundles on the roadways in rural areas before the unfortunate columns were driven through. But in many instances, Transnistrian peasants assisted the deportees openly, in full view of the soldiers accompanying the columns. Basing her research on an extensive study of testimonies and on her own interviews with survivors, Diana Dumitru summarized:

In the majority of testimonies, survivors mention that during the deportations (for example) some Transnistrian locals would come out to the streets and offer the Jews food and water as they passed through. In doing so, local civilians confronted greater danger than Bessarabians [who were mainly ethnic Romanians] of being attacked by the Romanian guards. (191)

Jews in the columns faced the real danger of starvation. As deportees were arriving from Bessarabia, Transnistria governor Alexianu himself described the situation as "quite serious." The Jews were arriving "in bad weather, with the roads impassable," he reported, which made "getting them to their destinations ... extremely difficult." He described the region to which 
the Jews were being directed as poor, the sanitary situation there as "very bad," and declared flatly, "I do not have the ability to give them even a piece of bread." 34 While there was no famine per se in Transnistria, Alexianu's comment reflected the reality that multiple significant demands left food in short supply. The Romanians shipped massive amounts of agricultural goods from Transnistria to Romania to support domestic consumption and help fulfill Romanian commitments to Germany. Romanian occupation authorities and military forces had to be provided for locally. The non-Jewish population, although subjected to severe food rationing, also had to be fed from local supplies. In addition, government policy established in Bucharest forbade shipping any food from Romania into Transnistria. Meanwhile, ethnic German ("Volksdeutsch") farmers in the territory, whose communities enjoyed semi-autonomy under the protection of the SS and Volksdeutsche Mittelstelle (VoMi), were not subjected to the same forced deliveries of crops and animals that the Romanians imposed on other local farmers, who were often stripped of most of what they produced. And in spite of agreements between the Romanian and German governments to the contrary, German military commanders seized food supplies, as well as other resources, in Transnistria, more or less at will, to provision German forces further east (Solonari 39-50).

The Jews who were pushed across the Dnister from Bessarabia arrived in Transnistria in terrible shape. Feeding them (and the Roma who came later) was the lowest priority of all in a situation of extreme food scarcity. A confidential report dated 27 September from the commander of border fortifications at the crossing point Rezeni-Râbniţa described their situation in the following terms:

they have reached such an advanced state of physical weakness following their march that the route which they travelled is dotted with graves. Insects crawl all through the filthy rags they are wearing, and the faces of these people, drawn by hunger, project the presence of disease .... The guards accompanying these transports have told me that only about half of the Jews have anything with which to buy food.... The others go hungry or survive on help from the others. The guards have also shared with me their

\footnotetext{
34 USHMM RG-25.003, Roll 126 (old 656), Folder 29, f. 331 [handwritten/counter illegible], Order No. 13842/CBBT [Comissariat for Bessarabia, Bukovyna, and Transnistria] of 5 November 1941, Vlădescu at Council of Ministers to Governor of Bessarabia, with excerpts from Alexianu's report on conditions in Transnistria. Alexianu's Report No. 2369 (perhaps 2363/partially illegible) of 1 November 1941, sent from Tiraspol, can be seen at USHMM RG-31.004/Odesa Oblast Archives, Roll 1, Fond 2242, Opis 1, Folder 677, ff. 99-110 [handwritten].
} 
impression that only twenty percent of the Jews will survive to their destination. ${ }^{35}$

Even as death consumed large numbers of deportees, it is clear that the food provided by locals to some Jews in the columns was a critical factor for those who survived the ordeal.

\section{GHeTtos, CAmPS, AND KiLLing Sites IN TRANSNistria}

The circumstances of Jews from Bessarabia and Bukovyna who survived deportation and forced marches into and through Transnistria and of local Jews from Transnistria itself varied considerably. Deportees from Bessarabia were sometimes put to forced labour and compelled to live out in the open, without shelter, in the dead of winter. Some deportees from Bukovyna were transported to Transnistria by train, arriving in better physical condition and, in the best of cases, able to find a degree of refuge, for longer or shorter periods, in larger towns. Deportees, as well as Transnistrian Jews from rural areas and Jews evacuated from Odesa, were concentrated in stables and pigsties or in the open on collective farms in the Holta district along the Buh River, where Romanian occupation forces denied them food, water, medicine, and outside contact. At the same time, Transnistrian Jews living in larger towns might be confined in ghettos but not expelled from surroundings that were familiar to them and not always completely isolated from neighbours who might offer some aid. Two special cases-the ghetto at Mohyliv-Podilskyi (Moghilev-Podolski) and the camp at Vapniarka (Vapniarca)-also merit attention because of their unique characteristics. It is important to recognize that in all of these locations, Jews suffered and succumbed to exposure, typhus, and other diseases, physical and emotional exhaustion, starvation, and murderous killing rampages. However, the circumstances differed significantly from place to place, including in regard to food policy and access to nourishment.

35 AMR, fond 1693-Comandamentul Etapelor de Est, dosar nr. 16, ff. 30-31, "Confidential Report No. 166 of 27 September 1941 on Jews Moved from Bessarabia to Transnistria," published in Trașcă, “Chestiunea evreiască," document 106, 268-69. 
Figure 2. Map of Romanian camps and ghettos in Northern Transnistria. Courtesy of the United States Holocaust Memorial Museum.

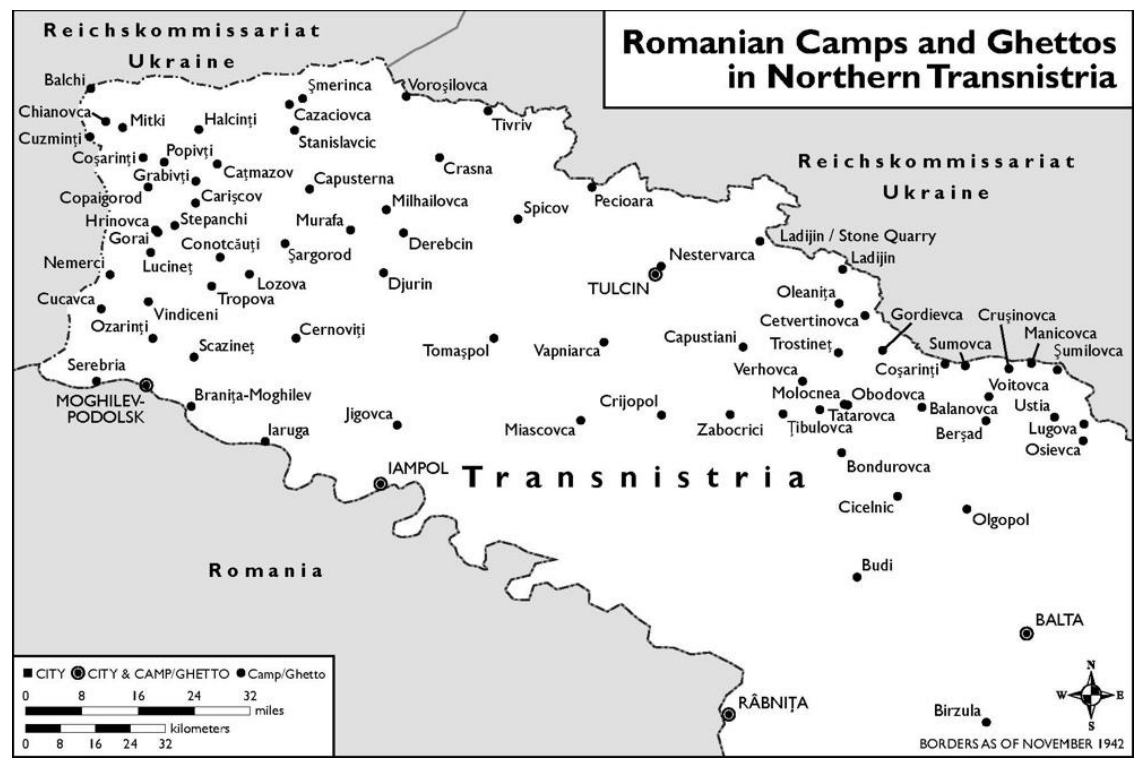

In Râbniţa, where the condition of deportees passing through was described above in such dire terms, a report from several months later, dated 19 April 1942, presented the situation of the 1,471 Jews in the town's ghetto in much more positive terms. Of the 293 men, 609 women, and 569 children, 635 were deemed unable to work, but the ghetto had a public kitchen that fed a single meal each day to 230 people, as well as a medical dispensary and a "very well-supplied" pharmacy. There were seventeen workshops in the ghetto employing 130 Jews, who were doing work mainly for the population of the city. While some employers of this forced labour had not paid labourers all of the money due to them, still, the report concluded, "the ghetto is in satisfactory condition, the houses whitewashed, sanitary conditions almost sufficient."

The report provided an even more positive picture of the small ghettofifty-six men, forty-two women, nine children-at Tiraspol (an additional seventeen Jews working for outside institutions were living outside the ghetto). The ghetto kitchen was able to serve two meals per day to the entire ghetto population. There were nine workshops inside the ghetto, employing thirty-eight Jews, and fifty-three Jews worked for various institutions of the military garrison and were paid two RKKS ("Reichskreditkassenscheine"- 
the occupation currency issued by Nazi Germany) per day for their labour. Even here, however, the report noted that many of the Jews had been brought to Tiraspol from elsewhere, but that their families, "often including minor children," had been abandoned in other localities. And despite all the positive statements in the early paragraphs of the report, the author also indicated that the ghetto was not able to continue to feed adequately the internees with the "income" it had. The author's final recommendation was that on days when bread was distributed in the city, a ration of one hundred grams of bread per person also be distributed in the ghetto.

The same inspection report provided a description of conditions that were far worse in the ghetto at Balta, second in size among Transnistrian ghettos only to Mohyliv. There were 514 men, 1,234 women, and 898 children in the ghetto. Of the adults, 698 were unable to work, and of the children, 700 were orphans ( 300 having lost both parents). According to the report, conditions were "bad," "filthy," and the Jews who had performed forced labour for different authorities had not been paid "for months," despite the government guideline that required payment of "two Marks [RKKS] per day for a skilled labourer and one Mark per day for unskilled." Some users of forced labour had "paid" labourers just 600 grams of cornmeal for a day of work, "which is unfair since a kilo of corn meal costs just 24 lei (40 pfennigs)." The central kitchen where 300 people eat, the report continued, "is dirty, poorly equipped, and poorly supplied. It serves a single meal per day, has difficulty obtaining food, and pays a high price for the food it is able to get...." 36

A year later the situation in Balta had not changed significantly. A report dated April 1943 described the houses in the ghetto as "miserable, with eight to ten people living in each room, infected air, and indescribable filth." The two orphanages were described similarly, with the added note that food was "insufficient, even bread being missing." In Râbnița, meanwhile, the situation had deteriorated. The houses on the two streets of the ghetto were "filthy," and the Jews had "no clothing." The report noted, however, with what in hindsight can be perceived only as extreme cynicism, that the sanitary situation had improved "following the death last year of ninety percent (of the ghetto inhabitants) of exanthematic typhus." 37 The combination of

\footnotetext{
${ }^{36}$ Arhivele Ministerului Afacerilor Externe (Archive of the Ministry of Foreign Affairs [of Romania]-AMAE), fond Problema 33, vol. 21, ff. 455-63, "Note of 19 April 1942 on the Jewish Ghettos in Transnistria," published in Traşcă, "Chestiunea evreiască," document 237, 497-502.

37 Arhivele Naţionale Istorice Centrale (National Central Historical Archive [of Romania]-ANIC), fond Cabinetul Ministrului de Interne, dosar nr. 48/1943, f.7+verso, "Report on the Situation of the Ghettos in Transnistria in April 1943," published in Trașcă, "Chestiunea evreiască," document 380, 768.
} 
malnutrition, unsanitary conditions, exposure, disease, and the passage of time proved deadly for Jews in ghettos all across Transnistria.

\section{Figure 3. Map of Romanian camps and ghettos in Southern Transnistria. Courtesy of the United States Holocaust Memorial Museum.}

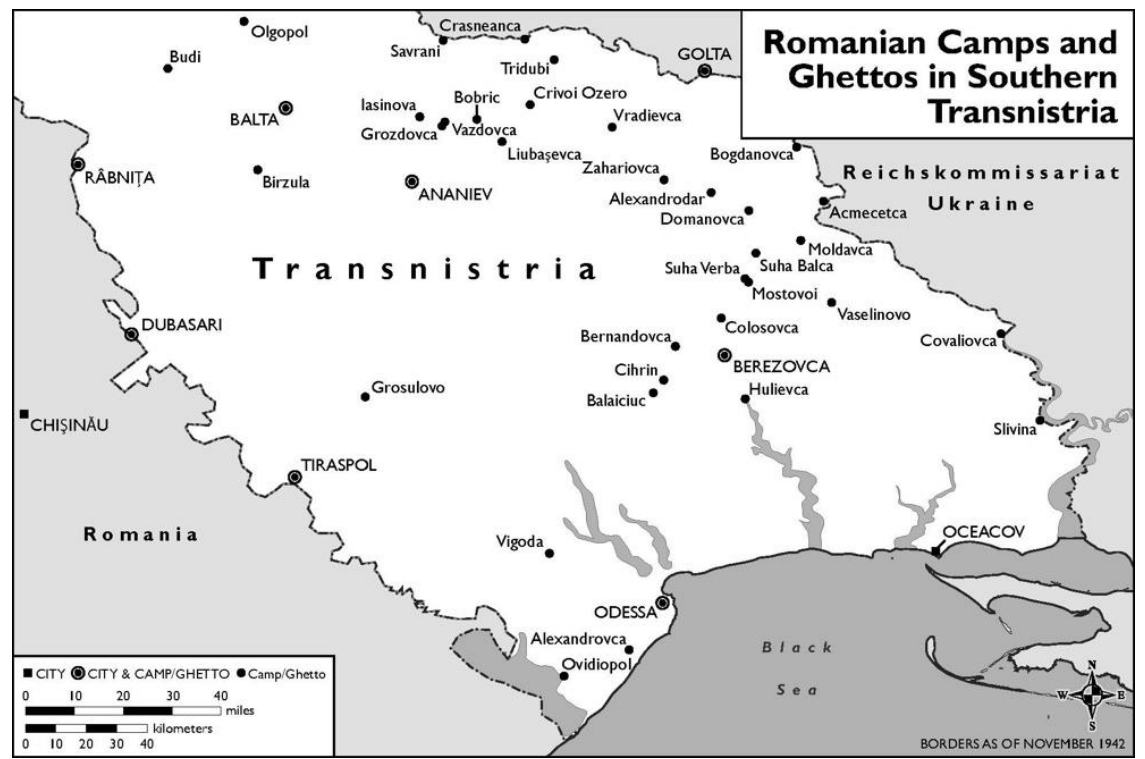

As problematic as maintaining an acceptable survival diet may have been in Transnistrian ghettos, the situation in camps established in more isolated locations was far more difficult. Neighbours and acquaintances who might have taken pity on the internees or with whom "arrangements" could have been made did not exist, and the food supply in marketplaces, sometimes accessible to ghetto inhabitants if they could sneak out long enough to reach a market, was also generally beyond the reach of the Jews penned up on collective farms or in makeshift work camps. In May 1942 the Romanian army's Bureau 7, responsible for Jewish affairs, provided a report on these camps to the Presidency of the Council of Ministers. The camps for Jews were set up under the direct authority of the Government of Transnistria and located in villages, on isolated terrain, and on collective farms. Guarded by gendarmes and local policemen ("armed Ukrainian guards"), the Jews "were not permitted to leave their localities [or] camps." "Those who violate this," the report continued, "are considered spies in time of war and sanctioned accordingly [underlined in the original] .... Every Jew 
has to take care of his own food and maintenance. Both hygiene and what it takes to stay alive are lacking ...."38

In such circumstances, survival could depend on taking the real risk of sneaking out of camp and into a nearby village to beg, barter, or work for something to eat, even in full knowledge of likely execution if caught. Many survivor testimonies focus on the potentially fatal risk required to avoid starvation. One survivor of the camp at Obodivka (Obodovca) told his story this way:

I arrived in the camp at Obodovca. It was enclosed with barbed wire, with guard observation posts. It was crowded, between 3,000 and 4,000 Jews ... they put us in a cowshed.... At night adults went into the village, the guards fearing partisans [and thus absent], and they were able to bring back something to eat from the Ukrainians .... We were not given any food in the camp. They took us out to work ... on the Subina state farm ("sovkhoz"), [and] it was our good fortune that the Ukrainian men had been taken into the Soviet army, and others were partisans in the woods, and there remained only women and children .... They [the Romanians] did not have people to do the work. I was twelve years old at that time, and together with my two brothers we worked there and managed to get something to eat. It was food not even a dog would eat, but we ate it then. We were also saved by Ukrainian women working near us who would bring food and hide it in the woods and show us where to look. They were afraid to hand us the food because there were gendarmes there also .... [One boy] was killed because he went into the woods and picked some wild apples. The gendarme saw him .... He beat him to death, and we buried him there in the forest. ${ }^{39}$

In her chapter on "Jews and Their Neighbors in Occupied Transnistria," Dumitru provides equally compelling examples of the ways in which Jews in the extreme circumstances of Transnistrian camps survived by begging, trading, working for, or even stealing food. Multiple entries in a collection of survivor testimonies published by the Romanian Institute of Recent History (Institutul Român de Istorie Recentă) contain similar examples. "The Pullover," a short autobiographical story by Romanian author and Transnistria survivor Norman Manea, provides a powerfully moving image, as seen through the eyes of a child, of Manea's mother bringing food (and a sweater) back to her family after a week of labour in a Transnistrian village (see Dumitru 196-209; Holocaustul evreilor români; Manea 3-15).

38 AMR, fond 5416-Marele Stat Major, Secţia I-a Organizare-Mobilizare, dosar nr. 3002, ff. 21-22, "Note 42071 of 31 May 1942 from Bureau Seven-Jews," published in Traşcă, “Chestiunea evreiască," document 263, 546-47.

${ }^{39}$ See interview of survivor Şabs Roif by Petru Clej, entitled "Am fost în groapa cu morți timp de o noapte," 1 November 2009, at http://acum.tv/articol/10505. Accessed 15 Aug. 2017. 
If state policy, antisemitic propaganda, the military chain of command, and widespread lack of humanity accounted for the terrible treatment of Jews by Romanian civil and military authorities early on, an added and accelerating factor that led to many of the camps in Transnistria being transformed into mass killing sites was fear, specifically fear of disease, and most particularly, fear of typhus. Significantly, while there is little evidence that German officials, who exercised certain administrative prerogatives that, in fact, infringed on Romanian authority in Transnistria, ever interfered in the formulation of Romanian food policy toward the Jews, they clearly shared the Romanian fear of typhus. They intervened directly to urge extreme action-liquidation of the Jews - in order to remove the danger of the disease spreading to the local population, and, even more importantly, to German military units transiting the territory and operating east of the Buh. ${ }^{40}$

Typhus appeared in the ghettos and camps where Jews from Bessarabia, rural Transnistria, and Odesa were crowded in the late fall and early winter of 1941. Records relating to the Chişinău ghetto show that cases of the disease had appeared there even before deportations began. However, when the number of cases began to rise among the non-Jewish population of Transnistria, fear of an epidemic sweeping across the entire territory became extreme. While sanitary and economic conditions in the territory were in general very poor, there is no question that some instances of the disease were the result of civilian contact with the exhausted, emaciated, starving, and disease-prone Jewish persec utees interned in Transnistrian camps and ghettos. A ledger for December 1941-January 1942 listing hundreds of cases of typhus among the non-Jewish population of Berezivka district provides a record, case by case, of where the sick person was being treated or isolated, when the disease was contracted, and how. The notes regarding the "how" question vary somewhat in form, but "contact with Jews," "contact with Jews from the camp," "Jews slept in her house," "from Jews from whom she bought clothes," "from contact with clothes bought from Jews in the camp" are typical of the comments in over ninety percent of the cases. ${ }^{41}$ With blame placed squarely on the Jews, and the Jews isolated, sick, and starving in cowsheds, pigsties, and on open ground, it is hardly surprising that mass shootings of Jews of a magnitude rarely seen elsewhere during the Holocaust-tens of thousands of Jews-took place in late 1941

40 On German advisors in Romania and the prerogatives of German authorities in Transnistria, see Solonari 31-62. On massacres carried out by Reich Germans and local Volksdeutsch, and German pressure for the mass execution of Jews in Holta district, see Ioanid, Holocaust 182-93.

${ }^{41}$ See "Table of Evidence of Contagious Disease" in USHMM RG31.004, Roll 19, Fond 2361, Opis 1, folder 59/1941. 
and early 1942 in Berezivka district, on the Domanivka, Akmechetski Stavky, and Bohdanivka collective farms in Holta district, and at other sites in Transnistria (see Ioanid, Holocaust 176-94).

\section{SPECIAL CASE: MohYLIV-PODILSKYI}

The largest ghetto in Transnistria, at Mohyliv-Podilskyi, was unique in many ways, not least because of the extraordinary efforts made by the chairman of the ghetto committee, Siegfried Jagendorf, to establish a foundry and other enterprises that proved useful to the Romanian occupiers. This allowed Jagendorf, through skilful and constant negotiation, to employ a significant number of Jewish deportees and keep them in the town, in many cases with their whole families, right up to the end of the Romanian occupation of Transnistria. The number of deportees who managed to remain at Mohyliv reached as high as fifteen thousand. At the same time, and in spite of Jagendorf's efforts, Romanian authorities constantly threatened and sometimes actually did expel Jews to other localities, where they were less likely to survive.

Conditions in Mohyliv were poor, and many Jews succumbed to typhus and other diseases, as they did elsewhere. In an official report on "The Situation of Jews in Transnistrian Ghettos," prepared in 1942, the author noted:

In most ghettos there are no toilets, and in Mohyliv there are feces everywhere .... The Jews pay rent to the Ukrainians for housing with their clothes, jewelry, and shoes. If they live in houses belonging to the local authorities, they pay rent as well .... There are about three thousand children in Mohyliv. The dispensary where sick children are interned made an odious impression on me .... It was something horrible to see .... I saw on the streets of the ghetto of Mohyliv women and children who had fainted from hunger because the food from the common kitchen is totally insufficient.... The authorities provide no help at all because they have to supply the urgent needs of the army. ${ }^{42}$

In a postwar testimony, Roza Schachter, a survivor at Mohyliv who came originally from Chernivtsi, also described the appalling deprivation and plight of the children in the Mohyliv orphanage:

\footnotetext{
42 AMAE, fond Problema 33, vol. 21, ff. 594-98, "Report [undated] on the Situation of the Jews in Ghettos in Transnistria," published in Trașcă, "Chestiunea evreiască," document 361, 728-31.
} 
The children picked through the garbage cans .... I think you've seen it on film, often they show how children were, at Auschwitz, too, with legs like sticks, bloated bellies, faces drawn; these children were like walking mummies. Unclothed and naked, in winter too, and they were digging for potato peels and whatever else they could find in the garbage cans, even while assistance was coming from inside Romania, from different organizations, for these children. ${ }^{43}$

Still, conditions in general were better in Mohyliv than in most other localities in Transnistria. The odds for survival at Mohyliv were improved by the fact that while many deportees from both Bessarabia and Bukovyna had passed through the city during the deportations, most of the deportees who managed to remain there were from Bukovyna, especially Chernivtsi and Dorohoi, and had arrived in Transnistria in much better condition than the Bessarabian Jews. In addition, Mohyliv was just across the Dnister from Bukovyna, and the internees managed to maintain communication with relatives and other contacts who remained in the large ghetto in Chernivtsi. Proximity to Romania also made it possible for Jagendorf to plead his case and garner substantial aid from the Jewish community leadership in Bucharest after the Antonescu regime decided to allow money and parcels of food and medicine to be transferred to deportees in Transnistrian ghettos and camps. The number of deportees who survived at Mohyliv exceeded ten thousand, an extraordinary number in light of the fact that only about fifty thousand of all deportees from Bessarabia and Bukovyna combined survived deportation (see Hirt-Manheimer).

\section{SPECIAL CASE: FoOd AS A WEAPON AT VAPNIARKA}

Located in northwestern Transnistria, Vapniarka became one of the many locations to which Romanian authorities sent the Jews they were expelling from their homes. In early 1942, nearly 1,200 Jews were sent there from the prison in Odesa. Several hundred Jewish deportees from Bessarabia and Bukovyna also were sent to Vapniarka. Many of these first contingents of Jews died during the typhus epidemic of the winter-spring of 1941-42. Jews who survived the epidemic were removed from Vapniarka in June 1942 and taken to other sites. Then, in August, the character of this specific site changed dramatically. Vapniarka was designated a special camp for "political" prisoners, to which Romanian authorities sent Jews who were incarcerated in Romania for alleged communist activity, Romanian Jews suspected of communist leanings, and Jews who had opted to move from

43 Interview of Roza Schachter in Holocaustul evreilor români 57-70. 
Romania to Soviet-occupied Bessarabia and northern Bukovyna during the year-long Soviet occupation of those territories (June 1940-June 1941). ${ }^{44}$

During September, nearly 1,200 Jews identified as falling within these categories were deported from Romania to Vapniarka. Among them were 407 (406, according to some sources) communist, social democratic, and other "political" prisoners from the Târgu-Jiu prison and seventy-two (eighty-seven, according to some sources) from the Caransebeş prison. NonJewish communist prisoners jailed in Romania, often in these same prisons, were not deported. When the new prisoners arrived, conditions at Vapniarka were horrifying. The camp buildings were in disrepair, and there was no running water in the camp. Nor had any food supplies been arranged for the arriving prisoners. ${ }^{45}$ Drawing on stocks of animal feed abandoned by retreating Soviet forces, the Romanians fed the prisoners a diet that consisted primarily of a fodder pea ("Lathyrus sativus") that was toxic to humans. The fodder pea diet very quickly wreaked havoc on the health of the prisoners, causing lesions, violent stomach cramps, diarrhea, impaired kidney function, spasmodic twitching of the extremities, and paralysis.

In response to this desperate situation and convinced that they were being intentionally poisoned, the prisoners went on hunger strike. Led by a camp committee dominated by communist activists and with guidance from Jewish doctors who had been arrested and sent to Vapniarka (some of them simply because Romanian authorities perceived all Jews as potential communist sympathizers), the internees refused to eat the fodder pea diet. The doctors in the camp, led by Arthur Kessler from Chernivtsi, addressed a series of written appeals to the camp commandant and directly to Transnistria Governor Alexianu. As a result, the government's medical examiner for Transnistria visited the camp. Persuaded by the diagnostic analysis provided by the incarcerated Jewish doctors, he proposed corrective action. In response, the internees' diet was modified, slightly at first, more significantly later, and prisoners were granted permission to receive packages of food, medicine, and clothing from Romania. Still, according to a report from late February 1943, 611 prisoners continued to show various symptoms of the disease, and 110 were severely afflicted.

\footnotetext{
44 Documents relating to this last category of internees were found by Romanian authorities in the Soviet embassy in Bucharest following the Axis attack on the USSR on 22 June 1941. For Antonescu's orders regarding the deportation of communist prisoners and the resulting implementation, see Traşcă, "Chestiunea evreiască," document 314, 653-54; document 328, 682-83; and document 338, 696-97.

45 Transnistria Governor Gheorghe Alexianu reported these conditions to Antonescu; see AMAE, fond Problema 33, vol. 20, ff. 67-68, "Communiqué No. 820 of 9 November 1942 from Alexianu to Ion Antonescu," published in Trașcă, "Chestiunea evreiască," document 347, 709-10.
} 
In early 1943, the Antonescu regime determined that more than four hundred of the internees had been sent to Vapniarka without justification. They were Jews but neither communists nor communist sympathizers. Instead of repatriation, however, as Jews, these prisoners were moved from Vapniarka to Transnistrian ghettos at Savran (Savrani), Olhopil (Olgopol), and Trykhaty (Trihati) (Ioanid, Holocaust 250-51). Then, in late 1943, with the Red Army approaching the region, Romanian authorities decided to close the camp. Some of the prisoners were sent to Transnistrian ghettos. A small group of fifty-four communists was sent to the prison at Rîbniţa, where on 19-20 March 1944, in the confusion that reigned as responsibility for the administration of Transnistria passed from Romanian to German control, all were executed by German Schutzstaffel (SS) men. The majority of the communists from the camp, 565 prisoners, were sent first to the Grosolovo ghetto, then taken back to Romania and interned again in the camp for political prisoners at Târgu Jiu, where many of them had been held before their deportation to Transnistria, eighteen months earlier.

There is an extraordinary variety and volume of documentation relating to this special Transnistrian camp, and a substantial share of it relates to the food supply and the consequences of the Romanians' attempt to use food as a lethal weapon. In addition to numerous unpublished memoirs collected by Romanian Jewish community organizations shortly after the war, sources range from camp administrative records of every kind to unique exchanges of memoranda between Jewish doctors in the camp and the government's medical examiner, to postwar trials of the officers who ran the camp. A postwar register of Jews interned in the camp on 1 September 1943, prepared by the World Jewish Congress office in Bucharest and based on a hand-written wartime list, records the names of the 706 internees who remained in Vapniarka after the removal of the prisoners deemed to have been improperly sent there. The diagnostic notes kept by Dr. Kessler as he tracked the paralysis and other afflictions the prisoners suffered have also survived. ${ }^{46}$

Details of the prisoners' diet are provided in files of "Supporting documents for expenses paid to feed the internees in Vapniarka camp" from the Odesa branch of the Ukrainian state archives. The December 1942 file, for example, reveals that only thirty lei (half of one RKKS) per day were allocated to feed each prisoner, and provides a daily accounting of the

\footnotetext{
46 The "Register of Jews interned in the Camp at Wapniarka-Transnistria on the 1st of September 1943" and Dr. Kessler's diagnostic notes are in the collections of the International Tracing Service at Bad Arolsen, Germany, and can be consulted in the ITS Digital Collection, List Material of various camps, 1.1.47.1, Folder 19, DOI 5160365-76 (VCC 176/c Ordner 19 in the paper records) and Folder 19a, DOI 5160449-5160553 (VCC 176/c Ordner 19a in the paper records), respectively.
} 
number of prisoners who had to be fed and the supplies purchased to feed them. On most days, purchases per prisoner consisted of four hundred grams of fodder peas, two hundred grams of bread, fifteen grams of salt, and five hundred grams of wood to feed the stoves. Every few days, between two and ten grams of oil were allotted per prisoner. On rare days, such as Christmas, meat was added to the supplies purchased. The meat was horse meat, and special documentation, still in the files, was required to record the purchase and slaughter of the horses. The documentation also reveals that on Christmas day in 1942, small amounts of carrots, onion, and potato were added to the diet. Subsequent files for the first three months of 1943 reflect a slight improvement in the diet, mainly through the more regular addition of potatoes and sour cabbage. A unique document records the slaughter of a thirty-eight-kilogram ram on 2 March to add some meat to the diet of the most severely afflicted internees in the prisoner infirmary. ${ }^{47}$

There are 450 files of former Vapniarka internees among tens of thousands of compensation claim files that were assembled by Romania's communist government in the early 1970s for the purpose of seeking a lump sum hard currency settlement from the Federal Republic of Germany. Many of these files include detailed medical records showing the decades-long paralysis, as well as other ailments, that were the legacy of Vapniarka's toxic diet. ${ }^{48}$ Recognizing that the Romanian government was unlikely to pass any payments on to the actual victims, the German government refused the claims.

\section{ROMA DEPORTEES TO TRANSNISTRIA}

The deportation of Roma to Transnistria by the Antonescu regime began later than the deportation of Jews. Starting in May and ending roughly at the end of October 1942, the Romanians deported approximately 25,000 Roma, some nomadic, others non-nomadic. According to the extraordinarily welldocumented research of Romanian scholar Viorel Achim, eleven thousand deported Roma perished in Transnistria, while approximately fourteen thousand survived and were permitted to return to Romania in the spring of 1944, as Romania lost Transnistria to the advancing Red Army. ${ }^{49}$ It is

\footnotetext{
47 USHMM RG-31.004, Reel 8, Fond 2255, Opis 1c, Folder 1617.

48 The collection of claim files is in the archives of the International Tracing Service. For a detailed survey of Vapniarka-related sources, see Shapiro, "Vapniarka."

49 Achim has published extensively on the subject. He contributed the chapter on "The Deportation of the Roma and Their Treatment in Transnistria" to the Final Report of the International Commission on the Holocaust in Romania. His twovolume study and document collection, Documente privind Deportarea Tiganilor în
} 
frequently asserted that among all of the groups that were persecuted as groups and deported to ghettos or camps by Nazi Germany and her Axis allies, the treatment meted out to Roma most resembled the treatment of Jews. The similarities could not be more striking than when the issues of food supply, malnourishment, and starvation among deportees to Transnistria are considered. Excerpts from the reports written by Romanian authorities illustrate this point.

In December 1942, an agent of the Romanian security police who spent two weeks on assignment in the Ochakiv (Oceakov) district of southeastern Transnistria, where many Roma deportees had been taken, reported:

While they were in the barracks at Oleksandrodar (Alexandrudar), the gypsies were living in indescribable conditions. They were insufficiently fed. Those able to work got 400 grams of bread per day, children and old people got 200 . They also got a bit of potato or salted fish, but in extremely small quantities. Due to malnutrition, some of the gypsies-the majorityhave lost so much weight that [they] have become mere skeletons. Every day, especially recently, ten to fifteen die. They were full of parasites. They received no medical visits .... They are naked .... In general the gypsies' situation is terrible and almost unimaginable. From this misery many of them have become mere shadows and almost wild. This is due to poor living conditions and poor food, and the cold as well. Because of the hunger to which they are subjected, they have frightened the Ukrainians by stealing .... (Achim, Documente 2: 24-29) ${ }^{50}$

Another report, filed a few days later by a special commission sent to Transnistria to investigate the situation of the non-nomadic Roma among the deportees, was even more grim. The colonel who authored the report noted that many of the Roma had been deported to Transnistria without the opportunity to bring any household items, extra clothes, or other possessions with them. While making short reference to orders regarding treatment of the Roma which, if implemented, might have offered the possibility of survival, the colonel then continued:

What is the reality? The gypsies are receiving 400 grams of oat or corn flour, and 200 grams for children. They have received nothing else-if they die they will die from hunger and cold .... [S]ince they arrived they have not

\footnotetext{
Transnistria, was awarded the Romanian Academy's prestigious Euxodiu Hurmuzaki Prize for a work of history. His Munca forțată în Transnistria: "Organizarea Muncii" evreilor şi romilor decembrie 1942-martie 1944, which deals with forced labour in Transnistria, is one of the rare works in which the experiences of Jews and of Roma during the Antonescu regime are treated in a fully integrated manner.

50 Document 249, Report of 5 December 1942, "On service executed in Oceakov district from 19 November to 4 December 1942."
} 
been given a single gram of salt, even though the prefecture has salt .... In general, the gypsies do not even have a pot in which to prepare food. With their funds exhausted, they have sold the clothes off their bodies, and now half of them are completely naked.... If the food supply for the gypsies does not improve, soon almost all of them will die. (Achim, Documente 2: 51$54)^{51}$

In the spring of 1943 conditions seemed only to have worsened. A gendarme in the Berezivka district reported the result of sending Roma from the camp at Kovalivka (Covaliovca or Covalevca) to surrounding villages to work:

Nothing was arranged in the communes to which they were sent, so the gypsies mostly just stood around outside, and because the temperature was very low, hundreds of gypsies died .... [A]ll the fields were strewn with corpses .... In the communes where they went, they are given no food .... The locals hate them, and when they find them alone, they beat them up; in general, they are left to die of hunger. The local [raion] authorities pay no attention to their fate. (Achim, Documente 2: 147-48) ${ }^{52}$

There is a remarkable consistency to all of the reports regarding the food situation. A report notes that in the camp at Holta neither the Jews nor the Roma had been given food for months, but "they are required to work while they are fainting from hunger" (Achim, Documente 2: 186-87). ${ }^{53}$ At Variushyne (Varuşino), where some food distributions were taking place, "the corn meal that is given to the gypsies is impossible to eat; the grain is just broken into quarters, many grains are whole, and there is an immense amount of sand in [it]" (Achim, Documente 2: 200). ${ }^{54}$ At Kovalivka, the chief of the gendarmerie post reported:

Today is the eighteenth day since the gypsies at Kovalivka have been given food. The gypsies have sold everything they had to buy food, now they have nothing left to sell and are eating the buds off fruit trees .... Because of hunger many gypsies are fleeing ... even at the risk of their lives, of being

\footnotetext{
51 Document 267, Report of 17 December 1942 of Commission No. 1 for investigation of the situation of non-nomadic gypsies evacuated to Transnistria.

52 Document 342, Report No. 91 of 17 March 1943 from Gendarmerie post Covalevca to Gendarmerie legion Berezovca.

53 Document 375, Report of 10 May 1943 from Gendarmerie Legion Golta to the Inspector General of the Gendarmerie.

54 Document 386, Report of 20 May 1943 from the Gendarmerie post Covalevca (stamp of Zlatonstove Gendarmerie post used) to the Military Gendarmerie of Landau district.
} 
shot, because they are condemned to die of hunger anyway. (Achim, Documente 2: 196-98) ${ }^{55}$

Consulting the memoirs and testimonies of Roma survivors of Transnistria adds the perspective and authentic voice of those who suffered, as well as details that even the gendarmes, soldiers, police, and civilian officials who observed and perpetrated the crimes against the Roma hesitated to put into their reports. Every one of the thirteen Romani survivor testimonies in a volume published in Romania in 2009 deepens the reader's understanding of the horrendous injustice and unspeakable suffering inflicted on these people during the war and the pain with which they saw, and later related, the agonizing and brutal deaths of their family members. In this regard, as in others, the fate of the Roma mirrored that of many Jews in Transnistria under Romanian rule (see Ioanid et al.).

Anghel Nedelea was a non-nomadic Roma deported from Piteşti, west of Bucharest, and survived internment in Mykolaiv (Nicolaev), Volodymyrivka (Vladimirovca), and Bohdanivka in Transnistria. In her testimony she returned repeatedly to the reality of hunger and the search for food:

Old people and children were dying of hunger, and we also .... In the winter there was no work, we just headed out to the villages.... You went to every house, and someone would give you a bit of corn, some "mămăligă" [polenta], that was all there was to eat. No other kind of food .... I got sick with typhus and was going to die, from minute to minute I was going to die. Because most people died from the typhus. And they found a horse, frozen by the Buh, left by the Russians. And the gypsies went and got it, cut it up and divided it up, and father managed to get 200-300 grams. And he gave it to me to make me well. And I ate that meat in that cold in that swarm [of people], and I got well. After that, what can I tell you, the fleas ate us alive.... (Ioanid et al. 214)

Another survivor, Gheorghe Irimia, who was eight years old when his family was deported from Medgidia in Dobrogea to Korenykha (Caranica) in Transnistria, spoke of the importance of each kernel of grain:

We were kept in captivity like prisoners; if you left the camp, they shot you; you did not have permission to leave the camp, but staying there you had nothing to eat. They gave you 600 grams of food a week .... You could see people picking up kernels of grain in the courtyard, on the street, wherever they were. And what they found they stuffed right into their mouths, because they were beside themselves with hunger and were dying of hunger. (Ioanid et al. 231-32)

\footnotetext{
55 Document 383, Report No. 216 of 18 May 1943 from Gendarmerie post Covalevca to Gendarmerie Legion Berezovca.
} 
Even these testimonies were not the most extreme. Pavel Zgonea, who was seventeen when he was deported to Fedorivka (Feodorovca), stated simply, "We found horse droppings, combed through the manure, scrubbed the kernels, and ate, biting our tongue; we ate grass like animals" (Ioanid et al. 260). In another case, Enuţa Spiridon described cannibalism as a consequence of the extreme starvation that afflicted Roma deportees during a typhus outbreak in 1943:

Whoever survived, survived; whoever did not, did not. We could hardly wait for someone to die to cut up and eat him, if you had nothing to eat.... [My father] died .... And when he died, I stayed and kept watch because they would come and cut him up and eat him; and I stayed and watched until they came and buried him .... From hunger, from hunger they were eating one another. And until they came and buried him I was worried. (Ioanid et al. 155-56)

Under normal circumstances one might be inclined to doubt such testimony. However, during a review of thousands of claim files submitted by Romanian Roma to the International Organization for Migration during the processing period of both Swiss and German forced labour settlements in the late-1990s and early-2000s, I personally encountered similar stories in a number of files, some relating to the same incident, and all convincing in their detail. Additional testimony and references to cannibalism in Transnistria appear in a recently published issue of the journal Etudes Tsiganes (Gypsy Studies, Paris), which is focused on "Territories of Extermination in Eastern Europe, 1941-1944" (nos. 56-57, 2017). Thus cannibalism, too, was a result of Romanian food policy and the starvation it produced among Jews and Roma deportees in Transnistria.

Famine and starvation were not the entire story in Romanian-occupied Bessarabia and Transnistria during World War II, but they were a permanent presence. Both Jewish and Roma deportees from Romania as well as Transnistrian Jews struggled to find enough food to survive.

Romanian state authorities, having established national policies of discrimination and deportation of both Jews and Roma largely independently of German influence, controlled the food supply available to these victims of persecution, on the basis of ethnicity. Prejudice against both targeted groups had deep roots in Romanian society. ${ }^{56}$ With the rise of Nazi

56 On the history of antisemitism in modern Romania, see the chapter I authored on "Background and Precursors to the Holocaust. Roots of Romanian Anti-Semitism. The 
Germany to dominance in Europe, the antisemitism and anti-Roma prejudices long present among Romanian elites and widespread in the general population became government policy in Bucharest. This background, more than any control exercised by Germany, shaped the murderous policies of the Antonescu regime and the attitudes of Romanian civilians who witnessed the concentration and deportation of the Jews of Bessarabia.

Bessarabian Jews suffered hunger, malnutrition, and disease in transit camps and ghettos before their deportation. In Transnistria, the Romanians shipped food out of the territory to Romania and also prioritized the food requirements of their occupation authorities and the Romanian military. Providing food to Jews and Roma was a lower priority than meeting the needs of the local non-Jewish population that lived between the Dnister and the Buh. Indeed, feeding Jews and Roma was the lowest priority. The extreme steps taken by both civilian and military occupation authorities to isolate the Jews and Roma, to prevent them from accessing food in local markets and punish those who tried, and to limit the help that might have been offered by those local civilian individuals who took pity on the victims all lead to the same conclusion. Romania's goal was to eliminate the Jews and reduce the perceived problem represented by the Roma. This made starvation of these ethnic groups an acceptable element of state policy.

Most of the Jewish and Roma victims of the Antonescu regime perished in Bessarabia and Transnistria. Many died of starvation or from the diseases that afflicted people subjected to extreme malnourishment. Others were the victims of mass shootings that the Romanians justified as necessary to prevent epidemics spreading to their own forces and the local population from the camps and ghettos where the perpetrators had concentrated their victims. At Vapniarka, the diet imposed by Romanian authorities was a particularly clear manifestation of the regime's use of "food as a weapon." Elsewhere in the territories that the Antonescu regime transformed into killing zones, the use of food policy as a weapon may have been less explicit, but it was no less deadly.

The Commission of Inquiry appointed by Ion Antonescu to investigate irregularities in the administration of the Chişinău ghetto asserted that in Bessarabia the lives of the Jews "ceased to represent a notion worth defending." 57 Long after the events discussed in this paper took place, some members of the Roma community continued to use the expression " $\mathrm{Du}$-te la

League of National Christian Defense and Iron Guard Anti-Semitism. The Anti-Semitic Policies of the Goga Government and of the Royal Dictatorship" in Final Report 1755.

57 Inquiry Report, Part 1. 
Bug!" ("Go to the Buh!"), when they wanted to tell someone to go to hell.58 Bessarabia and Transnistria were territories not of life, but of death during the Antonescu regime. What transpired there truly was a hell for the hundreds of thousands of Jews and tens of thousands of Roma who had the misfortune to find themselves in those territories under Romanian rule.

\footnotetext{
58 Use of this expression was first brought to my attention at a conference in 1981 by Nicolae Gheorghe, who was already establishing himself as a future leader in the Romani civil rights movement. A sociologist by training, Gheorghe was treated as a dissident during the communist era in Romania. Later he emerged as an important spokesperson for Romani rights internationally, including at the Organization for Security and Cooperation in Europe. Gheorghe impressed with his sensitivity and humanity, and he saw use of this expression as particularly painful to survivors of deportation to Transnistria. Gheorghe delivered an amazing paper at the conference, which sensitized me to the importance of including study of the fate of the Roma in study of the Holocaust era. Gheorghe feared the consequences he would suffer if his paper was published, however. The volume that emerged from the conference in 1981, unfortunately without Gheorghe's presentation, is Karnoouh, Paysans et Nations d'Europe centrale et balkanique. Born in 1946, Gheorghe passed away in 2013. His death was marked by a statement in the United States Senate on 11 September 2013 by Senator Ben Cardin, Chairman of the United States Commission on Security and Cooperation in Europe.
} 
Works Cited

Achim, Viorel. Documente privind Deportarea Ţiganilor în Transnistria. Enciclopedică, 2004. 2 vols.

---. Munca forțată în Transnistria: "Organizarea Muncii" evreilor şi romilor decembrie 1942-martie 1944. Cetatea de Scaun, 2015.

Ancel, Jean. The History of the Holocaust in Romania. U of Nebraska P and Yad Vashem, 2011.

---. Transnistria. Editura Atlas, Yad Vashem, 1998. 3 vols.

Ancel, Jean, editor. Documents Concerning the Fate of Romanian Jewry during the Holocaust. Beate Klarsfeld Foundation, 1987. 12 vols.

Axworthy, Mark. Third Axis-Fourth Ally: Romanian Armed Forces in the European War, 1941-1944. Hailer, 1995.

Benjamin, Lya, editor. Comisiunea Internaţională pentru Studierea Holocaustului în România: Documente. Polirom, 2005.

Carp, Matatias. Cartea Neagră: Fapte şi Documente-Suferinţele Evreilor din România, 1940-1944. Socec, 1946-47. 3 vols.

Dumitru, Diana. The State, Antisemitism, and Collaboration in the Holocaust: The Borderlands of Romania and the Soviet Union. Cambridge UP in association with the United States Holocaust Memorial Museum, 2016.

Evreii din România între Anii 1940-1944: Perioada unei Mari Restriști, 1940-1942. Federaţia Comunităţilor Evreiești din România, Centrul pentru Studiul Istoriei Evreilor din România, Hasefer, 1997. 2 vols.

Evreii din România între Anii 1940-1944-Problema Evreiască în Stenogramele Consiliului de Miniştri. Federaţia Comunităţilor Evreiești din România, Centrul pentru Studiul Istoriei Evreilor din România, Hasefer, 1996.

Final Report. International Commission on the Holocaust in Romania, Polirom, 2005.

Hirt-Manheimer, Aron, editor. Jagendorf's Foundry: Memoir of the Romanian Holocaust 1941-1944. By Siegfried Jagendorf, HarperCollins, 1991.

Holocaustul evreilor români: Din mărturiile supravieţuitorilor. Institutul Român de Istorie Recentă, Polirom, 2004.

Ioanid, Radu. The Holocaust in Romania: The Destruction of Jews and Gypsies under the Antonescu Regime, 1940-1944. Ivan R. Dee in association with the United States Holocaust Memorial Museum, 2000.

Ioanid, Radu, et al., editors. Tragedia Romilor Deportaţi în Transnistria, 1942-1945. Polirom, 2009.

Karnoouh, Claude, et al., editors. Paysans et Nations d'Europe centrale et balkanique. Maisonneuve et Larose, 1985.

Manea, Norman. “The Pullover.” October, Eight O'Clock, Grove Weidenfeld, 1992.

Megargee, Geoffrey P., et al., editors. The United States Holocaust Memorial Museum Encyclopedia of Camps and Ghettos, 1933-1945. Vol. 3: Camps and Ghettos Under European Regimes Aligned with Nazi Germany, Indiana UP in association with the United States Holocaust Memorial Museum, 2018.

Niri, A. Istoricul unui tratat înrobitor. Ştiinţifică, 1965. 
Shapiro, Paul A. The Kishinev Ghetto, 1941-42: A Documentary History of the Holocaust in Romania's Contested Borderlands. Alabama UP in association with the United States Holocaust Memorial Museum, 2015.

--.. "Vapniarka: The Archive of the International Tracing Service and the Holocaust in the East." Holocaust and Genocide Studies, vol. 27, no. 1, 2013, pp. 114-37. DOI: 10.1093/hgs/dct003

Solonari, Vladimir. A Satellite Empire: Romanian Rule in Southwestern Ukraine, 19411944. Cornell UP, 2019.

Traşcă, Ottmar. "Chestiunea evreiască” în documente militare române, 1941-1944. Institutul European and Institutul Elie Wiesel, 2010.

---. Relaţiile Politice şi Militare Româno-Germane, Septembrie 1940-August 1944. Argonaut, 2013.

Verenca, Olivian. Administraţia civilă română în Transnistria. Universitas, 1993. 